\title{
Sosialisasi dan Pelatihan Terkait Media Daring Google Classroom dan Google Form di Masa Pandemi Covid 19 pada Sekolah Dasar Negeri 23 Palembang (Socialization and Training Related to Online Media Google Classroom and Google Form throughout the Covid 19 Pandemic at
} State Elementary Schools 23 Palembang)

Muhammad Ichsan Siregar ${ }^{1 *}$, Nur Khamisah ${ }^{2}$, Sri Maryati ${ }^{3}$, Trie Sartika Pratiwi ${ }^{4}$, Lina Dameria Siregar $^{5}$, Hera Febria Mavilinda ${ }^{6}$, Yusnaini ${ }^{7}$, Nilam Kesuma ${ }^{8}$

Fakultas Ekonomi, Universitas Sriwijaya, Palembang ${ }^{1,2,3,4,5,6,7,8}$

ichsansiregar@fe.unsir.ac.id ${ }^{*}$, nurkhamisah08@fe.unsri.ac.id ${ }^{2}$, maryatisri@fe.unsri.ac.id ${ }^{3}$, triesartika_pratiwi@yahoo.com ${ }^{4}$, linadameria@fe.unsri.ac.id ${ }^{5}$, herafebria@fe.unsri.ac.id ${ }^{6}$, yusnaini@fe.unsri.ac.id ${ }^{7}$, nilamkesuma@fe.unsri.ac.id ${ }^{8}$

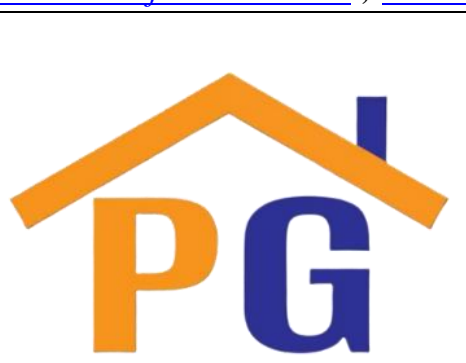

Riwayat Artikel

Diterima pada 28 September 2021 Revisi 1 pada 8 November 2021 Revisi 2 pada 19 November 2021 Revisi 3 pada 25 November 2021 Revisi 4 pada 30 November 2021 Disetujui pada 1 Desember 2021

\begin{abstract}
Purpose: This service aims to socialize and offer training related to the use of online study rooms through Google Classroom And Google Form to teachers and employees at State Elementary School 23 Palembang.

Method: The method used when carrying out this service activity is the lecture method and direct practice. Both provide material introduction to theory and direct practice of using Google Classroom and Google Form for both teachers and employees.

Results: From this service activity in the form of providing material and direct practice, both teachers and employees who tried Google Classroom and Google Form got good results. Teachers and employees understand the use of online media in the form of Google Classroom And Google Form.

Conclusions: After getting materials and practices for using online media, Google Classroom and Google Form, teachers and employees are accustomed to use these online media throughout the COVID-19 pandemic.

Keywords: Google Classroom, Google Form, State Elementary School 23 Palembang

How to Cite: Siregar, M, I., Khamisah, N., Maryati, S., Pratiwi, T, S., Siregar, L, D., Mavilinda, H, F., Yusnaini, Y., Kesuma, N. (2021). Sosialisasi dan Pelatihan Terkait Media Daring Google Classroom dan Google Form di Masa Pandemi Covid 19 pada Sekolah Dasar Negeri 23 Palembang. Yumary: Jurnal Pengabdian kepada Masyarakat, 2(2), 69-77.
\end{abstract}

\section{Pendahuluan}

Isu teknologi akhir-akhir ini berhubungan dengan perlengkapan yang dapat menangkap, menaruh, memproses, memperbaharui dan mengenakan kabar terkait fitur keras di dalam personal komputer mirip dengan mainframe, server, laptop serta personal digital assistant (Bodnar \& Hopwood, 2010). Isu teknologi juga menelaah bagaimana menggunakan perlengkapan elektronik terkait personal komputer, menganalisis serta mendistribusi (Asmani, 2011). Abdul Kadir \& Triwahyuni (2013) mendefinisikan teknologi data dan komunikasi menjadi suatu teknologi yang di dalamnya terdapat proses mengumpulkan, mencerna, menaruh, membuatkan serta menyajikan kabar.

Mengulas terkait bidang teknologi yang tidak terlepas dari kemajuan teknologi serta komunikasi merupakan salah satu contoh yang nyata terdapat di bidang pendidikan. Media juga bagian yang tidak terpisahkan dari proses belajar mengajar. Kata media dapat dilihat dalam bentuk jamak atau berasal 
dari kata medium dapat diartikan sebagai alat untuk memulai komunikasi (Daryanto, 2016). Media pendidikan ialah suatu mediator yang mempermudah pendidik membagikan modul bahan ajar dari setiap materi kepada pada siswa agar pendidikan bisa tercapai (Wulandari \& Jannah, 2018).

Menurut (Sadiman, Rahardjo, Haryono, \& Hardjito, 2014) media pendidikan mempunyai bermacam manfaat yang dapat membantu dan menolong proses pendidikan. Manfaat media Pendidikan antara lain:

1. Menanggulangi keterbatasan yang dimiliki siswa;

2. Mendapatkan cerminan secara jelas;

3. Membolehkan siswa mempunyai kedekatan yang eksklusif dengan lingkungannya;

4. Menanamkan konsep yang sahih, konkret dan realistis;

5. Meningkatkan asa dan atensi baru siswa;

6. Meningkatkan motivasi serta memicu siswa untuk belajar;

7. Mempermudah partisipan atau peserta didik menyamakan, mengamati, dan menggambarkan barang.

Menurut Daryanto (2016) kegunaan media pembelajaran antara lain:

1. Menyaksikan hal-hal yang ada disekitar;

2. Mendengar hal-hal yang ada disekitar;

3. Mengamati lingkungan sekitar;

4. Dapat membandingkan apa yang dilihat;

5. Dapat merespon lingkungan sekitar;

6. Melihat lingkungan sekitar;

7. Dapat merespon audiensi;

8. Dapat belajar sesuai dengan minat, bakat dan kemampuan.

Media pembelajaran terdiri dari media pembelajaran yang dilaksanakan secara tatap muka dan media pembelajaran online. Terkait media pembelajaran online bisa juga dikatakan sebagai model yang menggunakan teknologi data berbasis website yang dapat diakses jarak jauh sehingga proses pembelajaran yang dilakukan tidak hanya terpaku dalam ruang kelas tetapi bisa pula dicoba di manapun serta kapanpun. Hal ini sering juga disebut dengan model pembelajaran e-learning. Inovasi pendidikan e-learning membagikan contoh pendidikan baru dalam pembelajaran di mana mengantarkan kedudukan dan guna yang besar untuk dunia pembelajaran. Hal ini merupakan salah satu jawaban atas kekurangan serta kelemahan pembelajaran konvensional yaitu antara lain keterbatasan ruang dan waktu pada proses pembelajaran.

Pembelajaran yang menerapkan e-learning berguna untuk menaikkan daya guna serta fleksibilitas pendidikan. Lewat model pendidikan yang dicoba secara e-learning, modul atau materi pendidikan bisa diakses kapan saja. Disamping itu modul atau materi yang dapat diperkaya dengan berbagai sumber belajar termasuk multimedia yang dapat diperbaharui oleh pengajar (Nadziroh, 2017). Tidak hanya itu, e-learning bisa pula dikatakan sebagai pemanfaatan ataupun pemakaian teknologi internet dan website untuk membentuk pengalaman belajar yang baru. E-learning dapat diperhatikan sebagai pendekatan yang inovatif serta dapat dijadikan sebagai desain media penyampaian yang baik, terpusat pada pengguna, interaktif dan selaku area belajar yang memiliki berbagai kemudahan untuk siapa saja, di mana saja, dan kapan saja. Dengan adanya e-learning dapat mempersingkat waktu, biaya lebih murah, serta fleksibel (Rohmah, 2020).

Semenjak peristiwa pandemi covid 19 yang merebak di Indonesia kita dialihakan dengan proses belajar mengajar secara daring (dalam jaringan), sehingga membuat roda kehidupan seolah berjalan dengan lambat (Fanaqi, Nurkalam, Tias, Syahputri, \& Octaviani, 2020). Menurut (Romli, Safitri, Nurpratiwi, \& Hakim, 2021) pandemi Covid-19 telah membatasi kehidupan masyarakat. Masyarakat tidak bisa hidup bebas seperti sebelum terjadinya. Covid 19 sendiri ialah penyakit yang taraf penyebarannya sangat kilat. Penyakit ini desebabkan oleh virus corona yang melanda sistem respirasi insan (Firman, \& Rahayu, 2020). Virus corona menimbulkan penyakit flu biasa hingga sindrom 
respirasi kronis. Metode menghindari penyebaran Covid-19 dapat dilakukan dengan mejaga jarak dari orang yang terinfeksi. Lebih dari itu, Covid-19 juga memengaruhi dunia pembelajaran. Oleh karena itu, seluruh kegiatan pembelajaran yang semula dilakukan secara tatap muka, kini dilakukan secara daring ataupun pendidikan jarak jauh menggunakan teknologi.

Dengan perkembangan digitalisasi yang berhubungan dengan teknologi serta informasi dan komunikasi, pembelajaran tatap muka sebelum pandemi covid-19, kini berubah dan dapat memanfaatkan teknologi pembelajaran jarak jauh atau daring. Pemanfaatan teknologi dan informasi komunikasi dalam pendidikan tidak lagi bersifat pilihan, namun sudah menjadi suatu keharusan mengingat keadaan saat ini (Kuntarto, 2017). Selaku alternatif di kala pandemic, media yang dapat digunkan salah satunya adalah Google Classroom. Google classroom Menurut Hakim (2016) merupakan layanan berbasis internet yang disediakan oleh Google dengan sistem e-learning. Sistem ini terbuat untuk menolong guru membuat serta membagikan tugas pada pelajar.

Pengguna layanan ini wajib memiliki akun google. Menurut (Google, 2021) Google Classroom membagikan sebagian manfaat seperti: kelas dapat disiapkan secara instan atau mudah oleh guru dan guru dapat mengundang siswa atau murid pada kelas yang akan digunakan; murid dapat mengerjakan tugas dan mengirimkan jawaban dari tugas; mengefisiensi kertas dengan adanya proses pendidikan dengan model media daring. Selain itu, guru dapat membuat kelas, membagikan tugas, berbicara serta melakuan pengelolaan. Seluruhnya di satu akun, dengan pengelolaan yang lebih baik. Seluruh modul dan materi otomatis tersimpan dalam folder Google Drive. Selain itu, guru juga bisa mengirim pengumuman dan mengawali dialog kelas secara aktif. Siswa dapat mengumpulkan tugas modul antara satu sama lain dan terhubung di setiap kelas, bisa digunakan melalui aplikasi ponsel atau di era digital saat ini bisa disebut smartphone. Smartphone mempunyai manfaat dan berkelanjutan (Mikkael, Touana, \& Takrim, 2020). Smartphone berperan sebagai media agar dapat mengakses Google Document, Calender, Gmail, Drive serta Formulir. Google Classroom sangat terjangkau. Kelas dapat dipakai secara gratis dan tidak dipungut bayaran serta tidak terdapat akses iklan. Seluruh informasi dalam pengguna nyaman serta tersimpan.

Tidak hanya perlengkapan berbentuk media pendidikan daring semacam Google Classroom, kita pula dapat menggunakan media pendidikan daring semacam Google Form. Google form merupakan bagian dari komponen layanan yang terdapat di Google Document. Google form pula dipakai untuk melaksanakan aktivitas berbentuk latihan, tugas, atau survei secara daring (Sianipar, 2019). Menurut (Jahron, 2018) manfaat Google Form antara lain:

1. Membagikan tugas/latihan di Google Form;

2. Mengumpulkan hasil olah survei berbentuk komentar di Google Form;

3. Mengumpulkan informasi semacam video, audio, pdf, document, foto di Google Form;

4. Membuat formulir registrasi online buat sekolah di Google Form;

5. Membagikan data lapangan lewat Google Form.

Dengan melihat keadaan yang terjadi dan di mana kita diharuskan belajar dengan menjaga jarak dan belajar jarak jauh, maka perlu adanya persiapan yang harus dilakukan secara maksimal agar proses belajar mengajar tetap berjalan dan tidak tertinggal dari modul dan materi yang ingin disampaikan. Setiap sekolah harus mempersiapkan terkait pembelajaran daring. Ini merupakan bagian dari sebuah inovasi dalam menjawab sebuah tantangan yang dihadapi di dunia pendidikan saat ini (Qiyami, \& Nilamsari, 2021). Begitu juga Sekolah Dasar Negeri 23 Palembang harus mempersiapkan para guru dan karyawan untuk bisa menggunakan aplikasi media daring yang populer dari Google seperti Google Classroom Dan Google Form. Selain dipersiapkan dari pihak sekolah terkait persiapan pembelajaran daring bagi guru dan karyawan. Guru dan karyawan pun harus mepersiapkan terkait media pembelajaran daring selama masa pandemi covid 19.

Kami selaku dosen-dosen ingin memberikan pengabdian kepada masyarakat berupa sosialisasi dan pelatihan yang berhubungan dengan pembelajaran daring menggunakan Google Classroom dan Google Form dengan kondisi pandemi covid 19 yang diharuskan proses kegiatan belajar mengajar 
tetap berlangsung, yang membedakan hanya tempat. Tempat disini dilakukan secara daring/online. Pengabdian kepada masyarakat yang kami lakukan di Sekolah Dasar Negeri 23 Palembang bentuk pelaksanaan kami terhadap tri darma pergururan tinggi dibidang pengabdian. Kegiatan pengabdian kepada masyarakat ini ditujukan untuk memberikan sosialisasi dan pelatihan kepada Sekolah Negeri 23 Palembang. Agar guru dan karyawan bisa menggunakan media daring selama pandemi covid 19 berlangsung.

Kondisi yang terjadi sebelum kami melakukan sosialisasi dan pelatihan melalui diksusi santai, guru dan karyawan masih minim kemampuan dalam pengoperasian Google Classroom dan Google Form sehingga menjadi kendala dalam pembelajaran daring. Beberapa kendala yang dihadapi di antaranya: kurangnya pengalaman dan persiapan para guru dan karyawan dalam menghadapi pembelajaran secara daring, kurangnya pengalaman pengoperasian aplikasi Google Classroom maupun Google Form sebagai media pembelajaran daring. kendala ini menjadi salah satu penyebab kurang efektifnya proses pembelajaran daring.

Dengan adanya teori-teori sebelumnya dan kodisi diatas mendorong kegiatan pelaksanaan sosialisasi dan pelatihan terkait media daring Google Classroom dan Google Form dimasa pandemi covid 19 pada Sekolah Dasar Negeri 23 Palembang serta dapat memaksimalkan dan menambah kemampuan dan pengetahuan terkait media daring berupa Google Classroom serta Google Form dan membuat proses belajar mengajar kepada siswa menjadi efektif selama masa pandemi covid 19.

\section{Metode}

Metode yang dilakukan dalam kegiatan pengabdian masyarakat dengan tema sosialisasi dan pelatihan Google Classroom dan Google Form, ini adalah dengan cara paparan, ceramah, diskusi dan praktik. Hal ini dilakukan dengan tujuan agar guru dan karyawan dapat memahami materi sosialisasi dan pelatihan dengan baik dan dapat mempraktikkannya. Pengukuran tingkat keberhasilan sosialisasi dan pelatihan ini diperoleh dengan cara mampu membuat akun yang ada di Google Classroom dan Google Form yang diberikan sesudah pelaksanaan kegiatan dan juga hasil pengerjaan tugas yang diberikan. Setiap guru dan karyawan menyiapkan laptop dan email masing-masing setelah mendapatkan penjelasan dari materi yang diberikan. Selanjutnya guru dan karyawan segera mempraktikan. Adapun kendala yang dihadapi oleh guru dan karyawan, tim pengabdian langsung memberikan solusi dari permasalahan yang timbul. Adapun mekanisme pelaksanaan dan alur pengabdian antara lain sebagai berikut:

\section{Mekanisme Pelaksanaan}

1. Sosialisasi dan pelatihan terkait pengenalan dan perkembangan media daring secara umum.

Berbagai perkembangan media daring juga dapat digunakan untuk mendukung pelaksanaan proses pembelajaran secara daring atau online. seperti kelas-kelas virtual menggunakan layanan Google Classroom, edmodo, google meet, skype, zoom dan aplikasi pesan instan seperti whatsapp maupun telegram. pembelajaran daring atau online menghubungkan peserta didik dengan sumber belajarnya yang secara fisik terpisah atau bahkan berjauhan (tidak tatap muka di sekolah) namun dapat saling berkomunikasi, berinteraksi atau berkolaborasi. pembelajaran daring adalah bentuk pembelajaran jarak jauh yang memanfaatkan teknologi telekomunikasi dan informasi, misalnya internet.

2. Sosialisasi dan pelatihan terkait perkembangan media daring e-learning secara khusus seperti Google Classroom dan Google Form. Adapun tahapan Sosialisasi dan Pelatihan terkait perkembangan media daring e-learning secara khusus seperti Google Classroom dan Google Form terdiri atas tiga tahap, yaitu:

1) Persiapan: pada tahapan ini dilakukan pembuatan materi Google Classroom dan Google Form berupa slide persentasi dan juga penentuan tatap muka secara langsung di ruangan yang sudah disiapkan oleh pihak sekolah sebagai tempat yang akan digunakan dalam pelaksanaan pengabdian masyarakat berupa sosialisasi dan pelatihan;

2) Pelaksanaan: pada tahapan ini dilakukan pelatihan dengan memaparkan materi, ceramah, diskusi memberikan tugas untuk melihat hasil pelatihan yang telah disampaikan untuk 
mengukur peningkatan kemampuan peserta dalam menggunakan aplikasi Google Classroom dan Google Form yang diajarkan dalam sosialisasi dan pelatihan;

3) Evaluasi: pada tahapan ini dilakukan evaluasi dari hasil kegiatan sosialisasi dan pelatihan yang telah dilaksanakan. Evaluasi yang dilakukan setelah selesai memberikan materi, berdiskusi, memberikan latihan dan tugas serta memberikan tugas secara mandiri satu peserta satu tugas terkait evaluasi penilaian keberhasilan dan peningkatan kemampuan setelah sosialisasi dan pelatihan berupa pembuatan akun Google Classroom, menambah siswa, memberikan tugas di Google Classroom dan melihat tugas serta menggunakan form dari Google Form ketika mau membuat soal untuk siswa dalam hal proses evaluasi belajar mengajar. Hal itu ditujukan untuk menilai keberhasilan dari sosialisasi dan pelatihan yang diadakan.

\section{Alur Pengabdian}

1. Perencanan, Penetapan tema, obyek dan Tim.

2. Audiensi tahap 1 ke SDN 23 Palembang.

3. Audiensi tahap 2 ke SDN 23 Palembang.

4. Audiensi tahap 3 ke SDN 23 Palembang.

5. Audiensi tahap 4 ke SDN 23 Palembang.

6. Pelaksanaan sosialisasi dan pelatihan media daring e-learning seperti Google Classroom dan Google Form pada hari rabu tanggal 02 juni 2021.

7. Monitoring dan Evaluasi pada hari kamis tanggal 03 juni 2021.

\section{Materi yang disampaikan}

Adapun materi yang disampaikan terkait penggunaan media daring Google Classroom:

1. Memperkenalkan apa itu Google Classroom;

2. Memberikan alamat Google Classroom: https://classroom.google.com/ dan memastikan sudah terhubung sama email berupa email google;

3. Menjelaskan interface Google Classroom termasuk bagian-bagian yang ada pada Google Classroom;

4. Mempraktikkan cara membuat kelas termasuk membagikan kode kelas dan/atau link;

5. Menambahkan siswa;

6. Membuat folder materi/tugas/evaluasi;

7. Mengirimkan materi dari folder yang sudah dibuat.

Adapun materi yang disampaikan terkait penggunaan media daring Google Form:

1. Memperkenalkan apa itu Google Form;

2. Memberikan alamat Google Form: https://docs.google.com/forms/u/0/?tgif=d dan memastikan sudah terhubung sama email berupa email google;

3. Menjelaskan interface Google Form termasuk bagian-bagian yang ada di Google Form;

4. Mengelola Google Form sebagai media evaluasi;

5. Mempersiapkan soal untuk mengevaluasi pembelajaran;

6. Menambahkan fitur gambar;

7. Mengelola nilai serta waktu ujian;

8. Membagikan link terkait form yang sudah dibuat.

\section{Hasil dan Pembahasan}

\section{Bentuk Acara}

Terkait dengan pengabdian masyarakat mengenai "Sosialisasi Dan Pelatihan Terkait Media Daring Google Classroom dan Google Form pada SDN 23 Palembang pada hari Rabu dan Kamis, 2-3 Juni 2021 dengan jumlah peserta sebanyak 36 Orang.

\section{Solusi}

Pentingnya pengenalan tentang "Sosialisasi dan Pelatihan Terkait Media Daring Pembelajaran Online bertujuan agar Guru dan Karyawan memahami dengan maksimal terkait media pembelajaran online 
seperti Google Classroom dan Google Form serta bisa mengikuti perkembangan teknologi media pembelajaran secara online. Adapun solusi yang ditawarkan kepada peserta pelatihan Google Classroom dan Google Form, yang mana para peserta masih minim terkait media pembelajaran online berupa Google Classroom dan Google Form. Setelah ada sosialisasi dan pelatihan penggunaan media online dalam penggunaan Google Classroom dan Google Form mendorong para peserta untuk dapat memanfaatkan menu yang ada di Google Classroom dan Google Form sebagai salah satu sarana dalam pembelajaran online menggunakan media Google Classroom dan Google Form.

\section{Evaluasi Kegiatan}

Penilaian yang dilihat selama proses kegiatan berlangsung melihat ketika peserta berhasil menjalankan aplikasi media daring. Hal itu bisa dilihat dari:

1. Para peserta yang mengikuti pelatihan sangat semangat;

2. Ketika memberikan materi, para peserta aktif berdiskusi dan bertanya;

3. Setelah materi yang sudah disampaikan, para peserta langsung mencoba serta dibimbing oleh pemberi materi dan tim;

4. Para peserta dinilai terhadap tugas yang diberikan oleh tim terkait media Google Classroom dan Google Form. Setelah dinilai hasilnya para peserta mampu serta berhasil dalam membuat akun Google Classroom, mengisi materi pembelajaran, membuat tugas dan ujian termasuk memberikan evaluasi pembelajaran menggunakan Google Form.

\section{Foto Kegiatan}

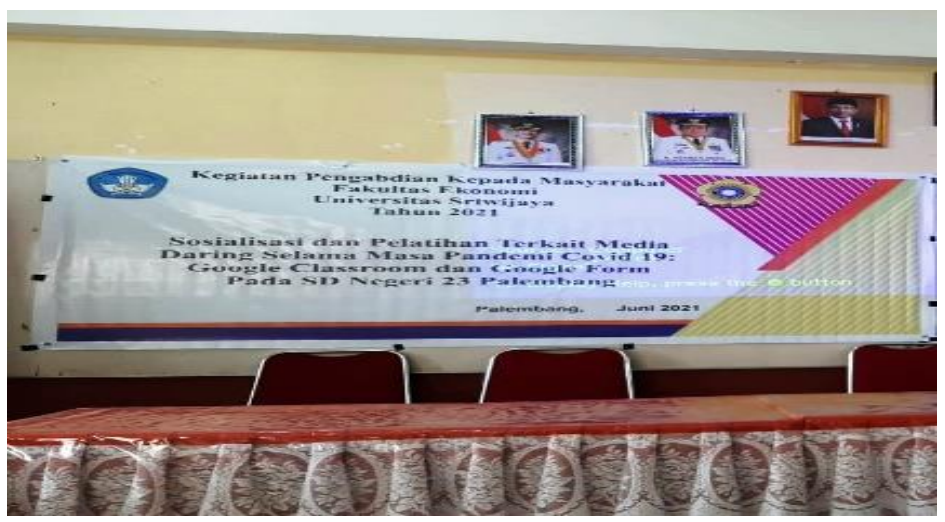

Gambar 1. Kegiatan pengabdian kepada masyarakat pada SDN 23 Palembang

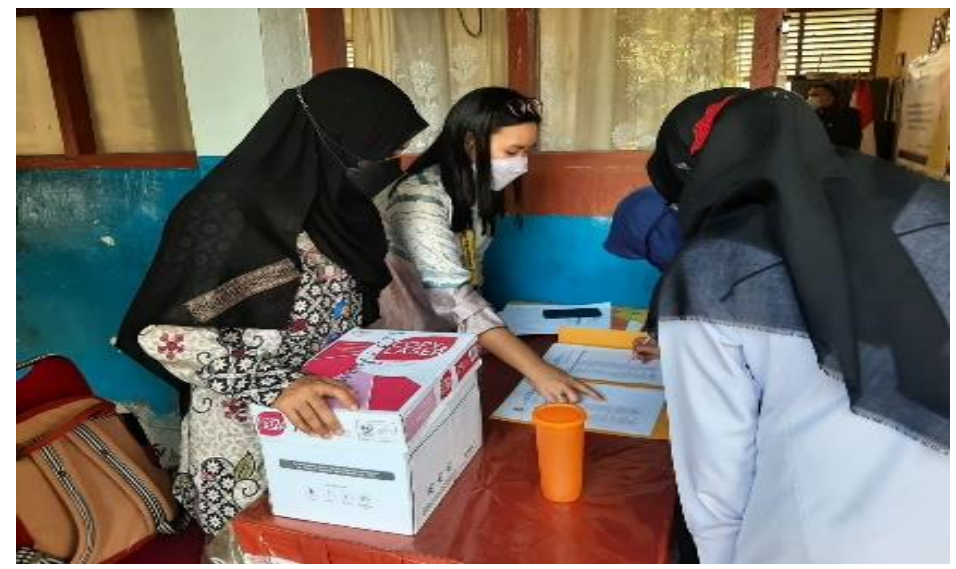

Gambar 2. Registrasi pendaftaran 


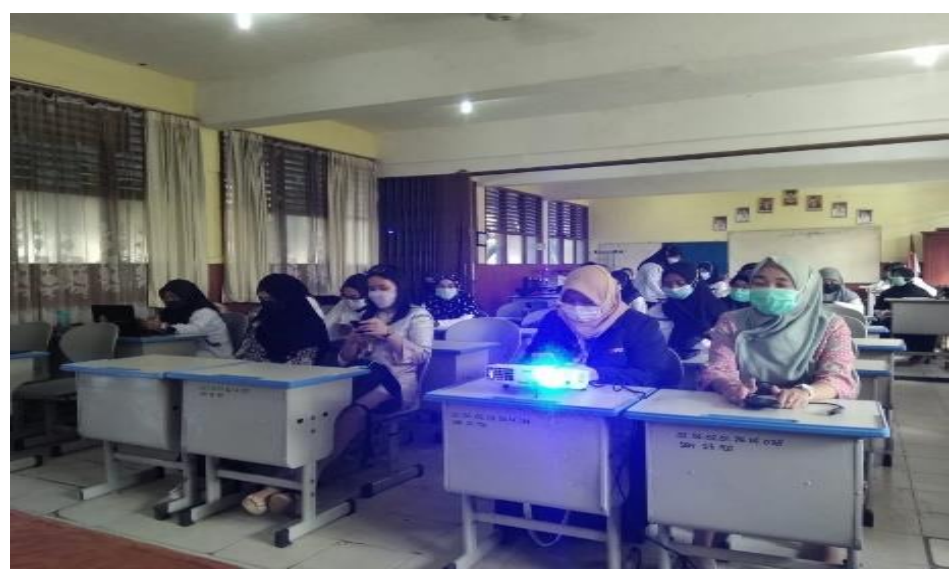

Gambar 3. Kegiatan sosialisasi dan pelatihan

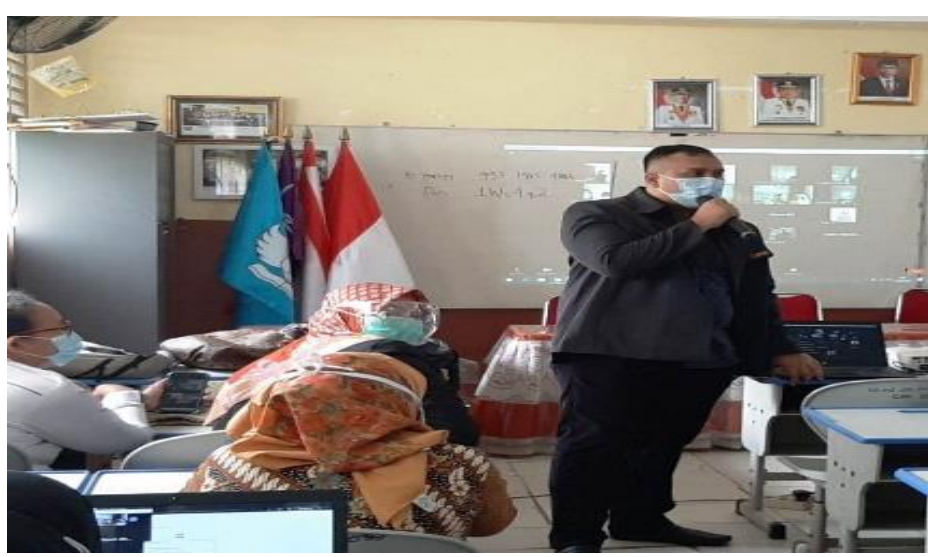

Gambar 4. Paparan materi

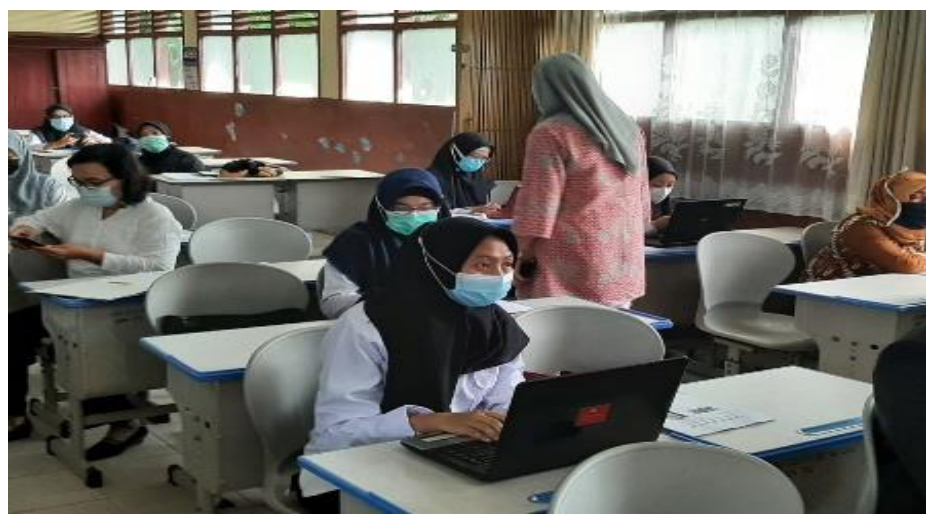

Gambar 5. Pelatihan

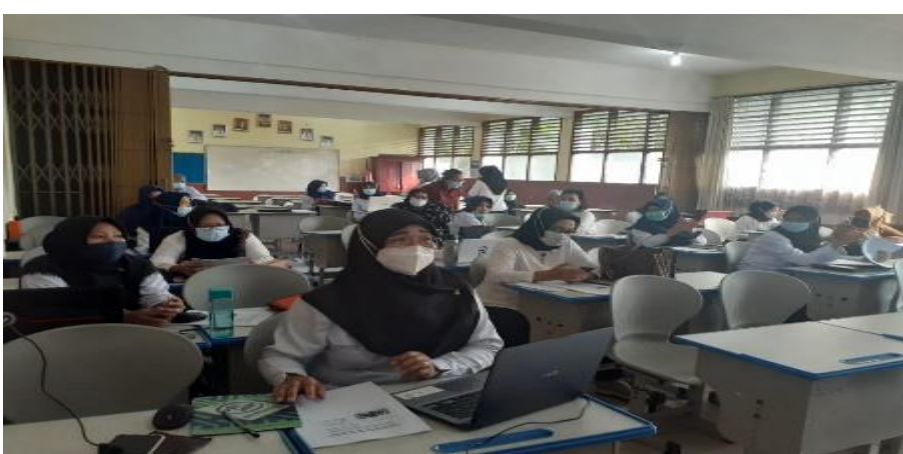

Gambar 6. Monitoring dan evaluasi

2021 | Yumary: Jurnal Pengabdian kepada Masyarakat/ Vol 2 No 2, 69-77 


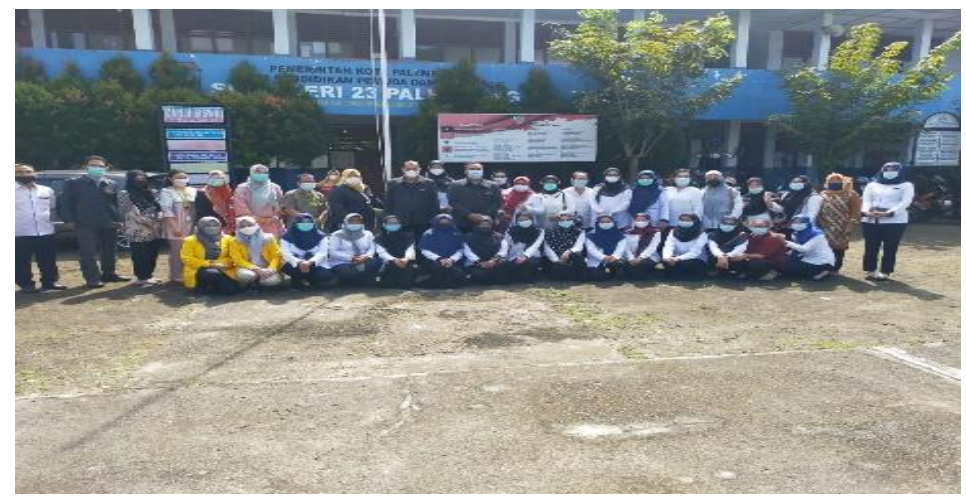

Gambar 7. Foto bersama

Adapun hasil dan pembahasan dari penjelasan sebelumnya, maka kegiatan pengabdian kepada masyarakat ini sangat bermanfaat dalam penggunaan media pembelajaran daring baik penggunaan Google Classroom maupun Google Form serta perlunya persiapan materi yang diajar, proses kegiatan belajar mengajar, evaluasi tugas maupun ujian. Semuanya ada di menu Google Classroom dan Google Form. Dari guru dan karyawan yang belum memahami terkait penggunaan media daring menjadi memahami dan terbiasa mempraktikkan penggunaan Google Classroom dan Google Form ketika memonitoring dan mengevaluasi kegiatan pengabdian tersebut.

\section{Kesimpulan dan Saran}

Berdasarkan hasil dan pembahasan sebelumnya, dapat disimpulkan beberapa hal sebagai berikut:

1. Kegiatan pengabdian masyarakat ini memberikan pengenalan berupa sosialisasi dan pelatihan media daring Google Classroom dan Google Form. Hasil yang didapatkan dari masing-masing peserta rata-rata masuk dalam kategori baik dapat dilihat ketika panitia melakukan monitoring dan evaluasi selama kegiatan berlangsung.

2. Peserta yang mengikuti kegiatan sosialisasi dan pelatihan terkait media daring Google Classroom dan Google Form sangat bersemangat dapat dilihat dari atusias peserta ketika sosialisasi dan pelatihan sedang berlangsung. Ketika diminta untuk mempraktekkan secara langsung antusias peserta tetap semangat untuk mencoba menggunakan media daring Google Classroom dan Google Form. Panitia melihat hasil akhir secara langsung dari peserta, rata-rata masing-masing peserta sudah bisa menyerap dengan baik dari materi yang telah disampaikan.

\section{Ucapan Terima Kasih}

1. Rektor Universitas Sriwijaya

2. Ketua Lembaga Penelitian dan Pengabdian Kepada Masyarakat (LPPM) Universitas Sriwijaya

3. Dekan Fakultas Ekonomi Universitas Sriwijaya

4. Kepala SDN 23 Palembang

5. Ketua Jurusan dan Sekretaris Jurusan Akuntansi

6. Guru-guru dan karyawan SDN 23 Palembang

7. Tim Pengabdian:

1. Muhammad Ichsan Siregar, S.E., M.S.Ak., CSRS., CSP., CSRA.

2. Nur Khamisah, S.E., M.Sc.

3. Sri Maryati, S.E., M.Sc.

4. Trie Sartika Pratiwi, S.E., M.Acc., Ak., CA.

5. Lina Dameria Siregar, S.E., M.M

6. Hera Febria Mavilinda, S.E., M.M

7. Dr. E. Yusnaini, S.E., M.Si., Ak., CA.

8. Nilam Kesuma, S.E., M.Si 


\section{Referensi}

Abdul Kadir dan Triwahyuni, C. (2013). Pengantar Teknologi Informasi Edisi Revisi. Yogyakarta: Andi.

Asmani, J. M. (2011). Tips Efektif Pemanfaatan Teknologi Informasi dan Komunikasi dalam Dunia Pendidikan. Jogjakarta: Diva Perss.

Bodnar, G. dan Hopwood. (2010). Accounting Information System. Upper saddle River, New Jersey: Pearson Education inc.

Daryanto. (2016). Media Pembelajaran. Yogyakarta: Gava Media.

Fanaqi, C., Nurkalam, F., Tias, D, A., Syahputri, S, D., dan Octaviani, N. (2020). Komunikasi kesehatan bagi pelajar dengan pendekatan peer education. Yumary: Jurnal Pengabdian Kepada Masyarakat, 1-9.

Firman, F., dan Rahayu, S. (2020). Pembelajaran Online Di Tengah Pandemi Covid19. Indonesian Journal of Educational Science (Ijes), 2(2), 81-89.

Google. (2021). google.com. Retrieved from https://www.google.com/search?q=menurut+google $\% 2 \mathrm{C}+$ google + clasroom+adalah

Hakim, A. B. (2016). Efektifitas Penggunaan E-Learning Moodle, Google Classroom Dan Edmodo.

Jahron, N. N. (2018). Pengembangan Tes Tertulis Pendidikan Agama Islam Berbasis Online Menggunakan Google Form Pada Materi Kewajiban Menuntut Ilmu Dan Haji Kelas X Sma Swadhipa Natar (Doctoral Dissertation, Uin Raden Intan Lampung).

Kuntarto, E. (2017). Keefektifan Model Pembelajaran Daring Dalam Perkuliahan Bahasa Indonesia Di Perguruan Tinggi. Journal Indonesian Language Education And Literature, 3(1), 53-65.

Mikkael, R. H., Touana, H., Takrim, M. (2020). PkM pelatihan peningkatan usaha mikro dalam mewujudkan smart business melalui smartphone di masa pandemi Covid-19. Yumary: Jurnal Pengabdian kepada Masyarakat, 35-40.

Nadziroh, F. (2017). Analisa Efektifitas Sistem Pembelajaran Berbasis E-Learning. Jurnal Ilmu Komputer Dan Desain Komunikasi Visual (Jikdiskomvis), 2(1), 1-14.

Qiyami, K. E., dan Nilamsari, W. (2021). Pengembangan Kreativitas Dan ProduktivitasSiswa-Siswi Sekolah Dasar Islam Al-Azhar8 Kembangan Jakarta Barat Melalui Program Media Creative Class. Yumary: Jurnal Pengabdian kepada Masyarakat, 39-49.

Rohmah, L. (2020). KONSEP E-LEARNING DAN APLIKASINYA PADA LEMBAGA PENDIDIKAN ISLAM. AN NUR: Jurnal Studi Islam, 255-270.

Romli, N. A., Safitri, D., Nurpratiwi, S., Hakim, L. (2021). Pelatihan Zoom Meetings dan Streaming Youtube untuk Pengembangan Komunitas Ngaji Online. Yumary: Jurnal Pengabdian kepada Masyarakat, 9-18.

Sadiman, A. S., Rahardjo, R., Haryono, A., Harjito. (2014). Media Pendidikan. Jakarta: Rajawali Pers.

Sianipar, A. Z. (2019). Penggunaan Google Form Sebagai Alat Penilaian Kepuasan Pelayanan Mahasiswa. Journal of Information System, Applied, Management, Accounting And Research, $3(1), 16-22$.

Wulandari, Y. \& Jannah, M. (2018). Penerapan Model Project Based Learning Untuk Meningkatkan Hasil Belajar Siswa Di Kelas V Min 38 Aceh Besar. Prosiding Seminar Nasional Biotik, 793797. 